Ritrýnd grein birt 31. desember 2018

\title{
Sköpun skiptir sköpum: Viðhorf tungumálakennara til skapandi kennsluhátta
}

\begin{abstract}
Ásta Henriksen
- Abstract Um höfundinn $\quad$ About the author Heimildir

Markmið pessarar rannsóknar var að kanna viðhorf nokkurra tungumálakennara í framhaldsskólum til skapandi kennsluhátta. Skoðað var hvað pað væri sem einkenndi helst skapandi kennsluhætti pessara kennara, hvort peim fyndist mikilvægt að búa til tækifæri fyrir nemendur til að vera skapandi og hvers konar kennsluaðferðum peir beittu helst. Einnig var athugað hvort eitthvað stæði í vegi fyrir pví að peir beittu skapandi kennsluaðferðum og hvað pá helst. Leitast er við að skilgreina hugtakið sköpun og fjallað er um sköpun í ljósi hugmynda fræðimannanna John Dewey, Lev Vygotsky, Elliot Eisner og Mihaly Csikszentmihalyi um nám og sköpun. Rannsóknin er hluti af rannsókninni Starfshæettir i framhaldsskólum og byggist á sjö viðtölum og jafnmörgum vettvangsathugunum hjá tungumálakennurum úr peirri rannsókn. Auk pess tók rannsakandi fjögur viðtöl til viðbótar og gerði tvær vettvangsathuganir.
\end{abstract}

Helstu niðurstöður eru pær að flestum kennurunum finnst mikilvægt að hlúa að sköpun, sem er grunnpáttur í menntun á Íslandi, meðal annars vegna pess að skapandi aðferðir vekja áhuga, pær stuðla að auknu sjálfstrausti nemenda og gera pá betur í stakk búna til að takast á við verkefni sem bíða peirra í framtíðinni. Nota peir að sögn fjölbreyttar aðferðir sem gefa nemendum peirra tækifæri til að vera skapandi. Hins vegar er ýmislegt sem stendur í vegi fyrir pví að peir noti slíkar aðferðir eins mikið og peir vilja. Niðurstöður rannsóknarinnar benda til pess að til að koma til móts við aðalnámskrá varðandi sköpun í námi purfi að efla skapandi nálgun í tungumálanámi í framhaldsskólum. Auka parf sjálfstæði nemenda og svigrúm kennara til samstarfs, bæði innan deilda og milli deilda, auk pess sem hlúa parf að menntun og endurmenntun kennara.

Efnisorð: sköpun, áhugahvöt, grunnpættir menntunar, námsmat, tungumálanám

\section{Inngangur}

Eitt af pví sem einkennir manninn er pörfin fyrir að skapa. Flestir pekkja gleðina sem getur fylgt pví að gera eitthvað skapandi og sköpun er mikilvægur páttur í að próa samfélagið áfram og ráđa fram úr vanda í síbreytilegum heimi, til dæmis í læknavísindum og umhverfismálum. Dví er við hæfi að sköpun skuli vera einn af peim sex grunnpáttum sem allt nám á að byggjast á í íslenskum leik- grunn- og framhaldsskólum (Mennta- og menningarmálaráðuneytið, 2011). Tungumálanám býður upp á endalausa möguleika hvað petta varðar, meðal annars vegna pess að tungumálakennarar hafa frjálsar hendur pegar kemur að vali viðfangsefna. Deir eru aðeins bundnir ákveðnum hæfniviðmiðum (Mennta- og menningarmálaráðuneytið, 2011) en geta sjálfir valið pemu til að vinna með. Dví er hægt að flétta sköpun inn í tungumálanám pannig að um leið og nemendur pjálfast í að tileinka sér erlend tungumál pjálfist peir í að hugsa á skapandi hátt og fái 
útrás fyrir pá sköpunarpörf sem í peim býr. Fannst mér, tungumálakennaranum, pví áhugavert аð skoða hvort sköpunarpátturinn er sýnilegur í starfi tungumálakennara í framhaldsskólum. Markmið rannsóknarinnar var að komast að pví hvort níu tungumálakennarar í framhaldsskólum sjá ástæðu til að hvetja nemendur sína til að vera skapandi og pá hvers vegna. Einnig fannst mér áhugavert að skoða hvers konar kennsluaðferðum peir beita og hvort eitthvað stendur í vegi fyrir pví að peir velji skapandi aðferðir.

\section{Bakgrunnur}

Hér verður fjallað um skilgreiningar á sköpun, hvað pað er sem einkennir skapandi kennsluhætti og mikilvægi pess að leyfa nemendum að vera skapandi. Að lokum verður skoðað hvað pað er helst sem fælir kennara frá pví að leggja verkefni fyrir nemendur sína sem gefa peim tækifæri til sköpunar.

\section{Skilgreining á sköpun}

Menntasamfélagið virðist ekki hafa komið sér saman um eina ákveðna skilgreiningu á pví hvað sköpun er og finna má margar skilgreiningar á hugtakinu (Cachia, Ferrari, Ala-Mutka og Punie, 2010). Yfirleitt er pó horft til ákveðinna pátta pegar hugtakið er skilgreint, svo sem peirra eiginleika sem skapandi einstaklingur parf að búa yfir og pess ferlis sem á sér stað við sköpun. Í pví ferli myndast gjarnan nýjar tengingar og afurð verður til.

Dó að í Aðalnámskrá framhaldsskóla (Mennta- og menningarmálaráđuneytið, 2011) sé sköpun ein af peim stoðum sem allt nám á að byggjast á er skilgreining á hugtakinu í námskránni fremur opin og óljós. Má pó lesa út úr pví sem par kemur fram, og í hefti um sköpun sem er hluti af ritröð um grunnpætti menntunar (Ingibjörg Jóhannsdóttir, Elísabet Indra Ragnarsdóttir og Torfi Hjartarson, 2012), að sköpun sé pað að virkja ímyndunaraflið til pess að finna nýjar leiðir við lausn viðfangsefna. Pannig leiðir ígrundun til pess að eitthvað er búið til sem er nýtt eða frumlegt eða veitir nýja sýn á fyrirbæri eða viðteknar venjur og hefur gildi fyrir okkur sjálf, nánasta umhverfi eða samfélagið (Mennta- og menningarmálaráðuneytið, 2011; Ingibjörg Jóhannsdóttir o.fl., 2012).

Í skýrslu National Advisory Committee on Creative and Cultural Education (NACCCE), All our futures: Creativity, culture and education (1999), er sköpun skilgreind á svipaðan hátt og í Aðalnámskrá framhaldsskóla. Í skýrslunni er lögð áhersla á pað að sköpun sé ákveðið ferli sem byggist á hugmyndaríkri athöfn (e. imaginative activity) og hefur pað markmið að leiða af sér eitthvað sem er frumlegt og hefur ákveðið gildi.

Skilgreiningar aðalnámskrár og skýrslu NACCCE um sköpun eru í takt við hugmyndir ýmissa fræðimanna. John Dewey (1938/2000) hélt pví fram að nemendur lærðu af pví að prófa sig áfram (e. learning by doing), finna sínar leiðir að lausn og öðlast pannig reynslu. Til pess að pað geti gerst purfi peir að vera virkir í náminu. Deir purfi að hugsa á gagnrýninn hátt og vera opnir fyrir pví að margar leiðir séu að takmarkinu. Elliot W. Eisner (2002) lagði einnig áherslu á pað að nemendur fengju tækifæri til að finna eigin lausnir og taldi hann mikilvægt að ekki væri stefnt að einni réttri lausn. Dannig fái nemendur tækifæri til að hugsa á gagnrýninn hátt og finna eigin leiðir að markinu. Dessa leið taldi hann auka áhuga nemenda á náminu. Mihalay Csikszentmihalyi (1996) telur einnig að pegar fólk fái að vera skapandi upplifi pað aukna gleði í lífinu og lifi lífinu til fullnustu. Við slíkar kringumstæður megi leiða að pví líkum að áhugi nemenda aukist og árangurinn verði betri. Bæði Dewey (1938/2000) og Csikszentmihalyi (1996) líta á sköpun sem órjúfanlegan pátt í pví að fólk lifir og hrærist í tilteknu samfélagi. Рað sama gerði fræðimaðurinn Lev Semyonovich Vygotsky (Moran og John-Steiner, 2003). Deir líta allir svo á að umhverfið hafi áhrif á samfélagið og samfélagið hafi einnig áhrif á umhverfið. Pannig sé pað skapandi framlag einstaklingsins sem viðhaldi menningunni og á sama hátt viðhaldi menningin sköpun 
einstaklingsins. Án samfélagsins væri einstaklingurinn ekki skapandi og fengi ekki tækifæri til að prófa sig áfram og án pess myndi samfélagið standa í stað. Pannig sé sköpun mikilvægur hlekkur í próun hvers samfélags. Loks má geta pess að Svanborg R. Jónsdóttir (2016) hefur sett fram tillögu um skilning og greiningu á skapandi starfsemi í formi líkans sem byggist á pví að skoða skapandi vinnu og afrakstur hennar út frá tveimur ásum. Annar ásinn sýnir hversu skapandi hugmyndir eru og hinn hvort skapandi hugmyndir hafa verið birtar eða kynntar eða ekki. Dannig er sköpun allt frá pví að vera eitthvað sem eflir einstaklinginn sjálfan til pess að nýtast heiminum öllum.

\section{Skapandi einstaklingur}

Einstaklingur sem talist getur skapandi býr yfir ýmsum eiginleikum. Hann er forvitinn (Edwards, 2001; Mennta- og menningarmálaráđuneytið, 2011), tilbúinn að prófa sig áfram (Amabile, 1979; Cropley, 2001), taka áhættu og leita lausna (Mennta- og menningarmálaráduneytið, 2011). Hann hefur góða aðlögunarhæfni og er hugrakkur (Cropley, 2001). Hann er einnig tilbúinn að mæta áskorunum, leggja hart að sér og sýna seiglu (Bandura, 1977; Grant og Dweck, 2003). Dar að auki gætir hann pess að taka hlutunum ekki sem gefnum heldur er hann tilbúinn að skoða pá á gagnrýninn hátt frá mismunandi sjónarhornum og mynda tengsl á milli hugmynda (Bowkett, 2005; Mennta- og menningarmálaráđuneytið, 2011; Sternberg og Kaufman, 2010).

\section{Kennsluhattir}

Til pess að nemendur geti próað með sér framangreinda eiginleika er mikilvægt að kennarar búi peim umhverfi sem gefur peim tækifæri til pess. Eitt helsta einkenni slíks umhverfis er pað að námið er nemendamiðað, p.e. að nemendur hafa áhrif á nám sitt og námsumhverfi (Collard og Looney, 2014; Cropley, 2001; Houtz, 1990; Lucas, 2001). Ímyndunaraflið fær að leika lausum hala og nemendur fá tækifæri til að finna ýmislegt út sjálfir í stað pess að leita eftir hinu eina rétta svari og pannig öðlast peir dýpri skilning á viðfangsefninu (Cropley, 2001; Lucas, 2001; Starko, 2014) og verða líklegri til að sýna frumkvæði (Little, 2003). Einnig fá peir verkefni sem krefjast pess að peir myndi heild úr ólíkum páttum pví slík vinna er líkleg til að stuðla að sköpun (Amabile, 1979; Brookhart, 2010; Starko, 2014, Timperley, Wilson, Barrar og Fung, 2007). Pá er mikilvægt að fylgja eftir áhuga nemenda (Lucas, 2001).

\section{Stuðningur við skapandi starf}

Stuðningur skólastjórnenda og samstarfsfólks er nauðsynlegur pegar kennarar vilja taka upp skapandi kennsluhætti. Yfirleitt er erfitt að breyta venjum og pað felur í sér ákveðna áhættu svo að mikilvægt er að skólastjórnendur styðji vel við bakið á kennurum. Deir purfa í raun að búa til jarðveg fyrir skapandi starf (Collard og Looney, 2014; Ingibjörg Jóhannsdóttir o.fl., 2012). Mikilvægt er að kennarar hafi svigrúm til að prófa sig áfram, og einnig parf að hvetja til samvinnu milli kennara, skólastjórnenda og fólks sem hefur sköpun að atvinnu. Skólinn parf pannig að vera opinn fyrir umhverfinu og samfélaginu pví pá verða nemendur forvitnir og opnir fyrir pví að upplifa eitthvað nýtt (Anna Jeeves, 2013; Collard og Looney, 2014).

\section{Námsmat}

Degar sköpun er metin er mikilvægt að meta ekki aðeins afurðina heldur einnig sköpunarferlið. Fyrst parf að meta hvert vandamálið er, síðan parf að meta gæði peirra hugmynda sem skjóta upp kollinum, og að lokum afurðina sem verður til eftir skapandi ferli (Collard og Looney, 2014). Ekki hafa verið próaðar margar aðferðir við slíkt mat og er pað að hluta til vegna pess að ekki er til skýr skilgreining á pví hvað sköpun er (Collard og Looney, 2014). Раð að nota sóknarkvarða (e. rubrics) getur pó hjálpað til við að meta verkefni. Dæmi um slíkt er líkan sem Lucas og félagar próuðu. Deir byrjuðu á pví að skilgreina fimm grundvallarhugtök sem tengjast eiginleikum sem 
skapandi einstaklingar purfa að hafa, en peir eru að vera forvitinn (e. inquisitive), prautseigur (e. persistent), samvinnufús (e. collaborative), hugmyndaríkur (e. imaginative) og agaður (e. disciplined). Síðan skilgreindu peir prjú undirhugtök undir hvert pessara hugtaka og próuðu pannig tæki til pess að fylgjast með breidd og dýpt framfara nemenda (sjá mynd 1) (Lucas, Claxton og Spencer, 2013).

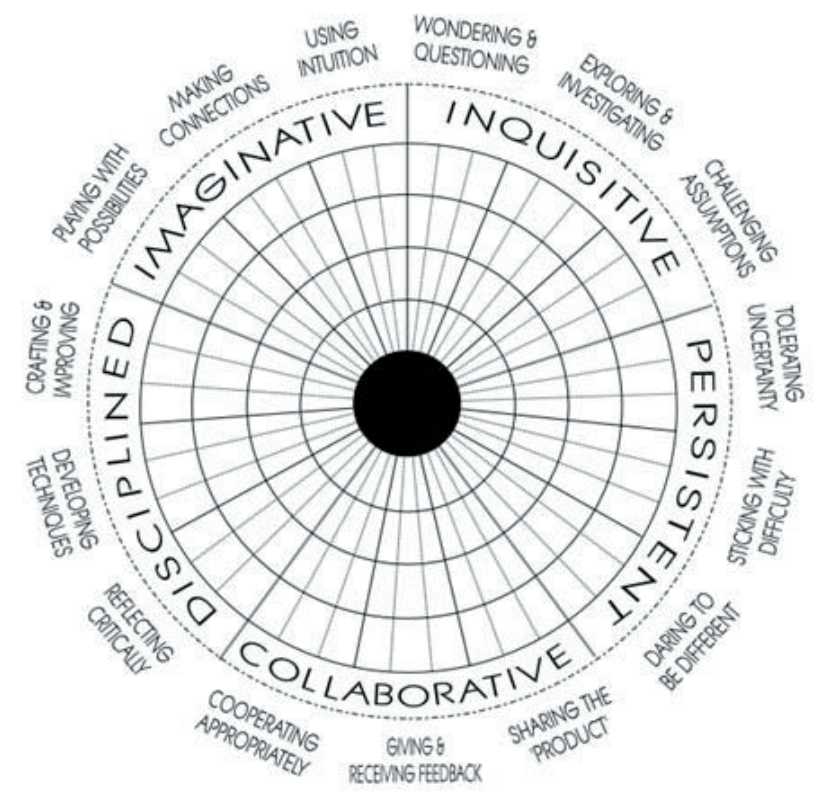

Mynd 1. Sóknarkvarði til að meta sköpun (Lucas o.fl., 2013, bls. 18).

\section{Kynning verkefna}

Mikilvægt er að nemendur fái að kynna verkefni sín og ferlið sem liggur par að baki. Með pví аð skoða ferlið, ekki aðeins útkomuna, myndast pekking á pví hvernig nemendum finnst best að vinna og pað að sýna verkefni er hvetjandi auk pess sem nemendur bjálfast 1 gagnrýninni hugsun pví peir skoða bæði pað sem vel tókst til með og pað sem betur mætti fara (Bamford, 2011; Dam, 1998; Mennta-og menningarmálaráđuneytið, 2011). Auk pess geta kynningar á skapandi verkefnum stuðlað að aukinni sköpun í samfélaginu (Svanborg R. Jónsdóttir, 2017).

\section{Mikilvægi pess að gera nemendum kleift að vera skapandi}

Skapandi verkefni auka áhuga nemenda pví sterk tengsl eru á milli innri hvatningar og sköpunar. Innri hvatning er ekki aðeins ánægjan af pví að læra eitthvað nýtt heldur einnig pað að vilja læra eitthvað nýtt, kunna að meta pekkinguna og hæfnina sem við tileinkum okkur (Starko, 2014). Til að rækta innri áhugahvöt purfa verkefni að vera fjölbreytt og jafnvel nýstárleg og höfða til nemenda. Ef nám á sér stað fyrir innri áhugahvöt verður skilningur dýpri og áhuginn eykst (Trilling og Fadel, 2009).

Skapandi aðferðir stuðla ekki aðeins að auknum áhuga nemenda heldur geta pær líka haft jákvæð áhrif á kennara, bæði persónulega og í starfi. Kennarar verða áhugasamari um vinnu sína og proska sinn í starfi og verða meira skapandi sjálfir pví peir fá tækifæri til að próa og nýta nýja færni og pannig eykst sjálfstraust peirra í starfi (Lamont, Jeffes og Lord, 2010, Starko, 2014, Svanborg R. Jónsdóttir, 2017).

Mikilvægt er í hinum síbreytilega heimi að pjálfa huga sem eru opnir og tilbúnir að sjá nýjar lausnir. I Aðalnámskrá framhaldsskóla (Mennta- og menningarmálaráduneytið, 2011) kemur fram að sköpun snúist meðal annars um lausnir viðfangsefna og leit að nýjum möguleikum og pannig tengist hún sjálfbærni. Mikilvægt er fyrir okkur að próa nýjar leiðir, til dæmis í 
læknavísindum, og finna lausnir á umhverfisvandamálum. Til pess að pað geti átt sér stað parf ungt fólk að pjálfast í að hugsa á gagnrýninn hátt og leita lausna á vandamálum. Bjálfun í að finna lausnir er pví með mikilvægari eiginleikum sem nemendur 21. aldarinnar purfa að búa yfir (Bamford, 2011; Craft, 2010; Dam, 1998; Trilling og Fadel, 2009). Dar sem ekki er endilega vitað hvers konar hæfni er nauðsynlegt að búa yfir í framtíðinni er mikilvægt að skólinn hugsi út fyrir hefðbundið námsefni og hlúi að mikilvægum eiginleikum, eins og bví að vera sveigjanlegur og geta aðlagast og pora að takast á við hið óvænta (Cropley, 2001). Að lokum má nefna að í Aðalnámskrá framhaldsskóla er lögð áhersla á að í sköpun felist mótun viðhorfa og gildismats (Mennta- og menningarmálaráduneytið, 2011) pannig að skapandi verkefni geta meðal annars stuðlað að pví að nemendur verði umburðarlyndir og víðsýnir.

\section{Hindranir sem kennarar standa frammi fyrir}

Ýmislegt fælir kennara frá pví að bjóða nemendum upp á skapandi verkefni. Eitt af pví er að peim getur fundist erfitt að meta slík verkefni, en pað er jafnvel stærsta hindrunin sem kennarar standa frammi fyrir pegar peir vilja fjölga skapandi verkefnum (Cizek, 2001; Hamilton, Berends og Stecher, 2005; Lucas o.fl., 2013). Par af leiðandi eru kennarar líklegri til að velja verkefni sem auðveldara er að meta og pá gjarnan pannig úr garði gerð að eitt rétt svar er við hverri spurningu (Collard og Looney, 2014). Hins vegar eru til tæki sem hægt er að nota við mat skapandi verkefna (sbr. Lucas o.fl., 2013).

Önnur ástæða fyrir pví að kennarar forðast að leggja verkefni fyrir nemendur sína sem reyna á að peir séu skapandi er sú að í slíkum verkefnum purfa peir að slaka á taumnum og nemendur að fá aukið vald. Kennarar geta orðið óöruggir pegar peir breyta kennslu sinni pannig og fundist nemendur ekki læra nóg ef peir stýra ekki hverju skrefi sem peir taka. Rannsókn Hafdísar Ingvarsdóttur (2004) sýnir að kennurum getur fundist erfitt að losa takið pví pá muni nemendur „ekki vinna verkið“ (bls. 476). Deim getur einnig fundist erfitt að slaka á taumnum vegna pess að peir eru hræddir um að missa stjórnina og sú tilfinning, sem kölluð hefur verið óttinn við óreiðuna (e. chaos angst), er ekki góð (Dam, 1998; Svanborg I. Jónsdóttir og Allyson Macdonald, 2011; Hjördís Porgeirsdóttir, 2018). Nemendurnir sjálfir geta líka verið íhaldssamir og óöruggir og erfitt getur reynst fyrir pá að taka við pví valdi og ábyrgð sem fylgir skapandi námi. Deim getur fundist kennarinn vera að vanrækja starf sitt í slíku umhverfi (Dam, 1998; Hafdís Ingvarsdóttir, 2006; Svanborg R. Jónsdóttir, 2017).

Ófullkomin tímastjórnun er enn ein hindrunin. Helsta ástæðan er sú að námskrár og námsáætlanir eru ofhlaðnar og kennarar hafa pví ekki tíma til að leyfa nemendum sínum að vinna skapandi verkefni (Cachia o. fl., 2010; Collard og Looney, 2014). Rannsókn Gerðar G. Óskarsdóttur (2012) sýnir að námsefnið stýrir námi töluvert við upphaf framhaldsskóla par sem yfirferðin miðast við að „,komast yfir“ ákveðið marga kafla. Dað sama sýnir rannsókn Hafdísar Ingvarsdóttur (2004) á enskukennslu, en par kemur fram að kennslubókin stýrir miklu í neðri áföngum.

Ýmsir aðrir tálmar verða á vegi kennara og hindra að peir leggi verkefni fyrir nemendur sína sem gefa peim færi á að vera skapandi. Má par nefna ónæga pátttöku skólastjórnenda í peim breytingum sem nauðsynlegar eru til að auka hlut sköpunar í námi. Rannsóknir Cachia o.fl. (2010) og Berland (2013) sýna að mikilvægt er að kennarar fái leiðbeiningar um pað hvernig peir geti próað skapandi starfshætti. Dví virðist sem kennarar purfi að yfirstíga margvíslegar hindranir ef peir ætla að bjóða nemendum sínum upp á fleiri skapandi verkefni, og vera tilbúnir að takast á við hið óvænta.

\section{Námskrá}

Til pess að sköpun fái notið sín parf að huga að peim námskrám sem kennarar starfa eftir. Endurnýja parf námskrá skólanna og námsáætlanir pví kennarar kvarta oft undan pví að peir purfi að fara yfir of mikið námsefni (Collard og Looney, 2014). Detta hefur pær afleiðingar að 
ekki gefst tími til pverfaglegrar samvinnu, heimsókna út fyrir veggi skólans eða til pess að leggja skapandi verkefni fyrir nemendur. Ekki er mikill tilgangur í pví að æða í gegnum námsefni á svo miklum hraða að nemendur fái ekki tækifæri til að öðlast skilning, móta ný tengsl eða próa innsýn í ópekkt svið (Collard og Looney, 2014).

\section{Aðferð}

Í rannsókn pessari varð eigindlegt rannsóknarsnið fyrir valinu. Í eigindlegum rannsóknum er gögnum safnað pannig að rannsakandi er á staðnum og upplifir hlutina og henta slíkar aðferðir vel ef skoða á rannsóknarefnið á dýptina (Lichtman, 2013), en pað er einmitt tilgangur pessarar rannsóknar. Byggist rannsóknin að mestu leyti á viðtölum en einnig eru vettvangsathuganir hjá viðmælendunum hafðar til hliðsjónar. Aðferðin var notuð til að fá svör við eftirfarandi rannsóknarspurningum:

1. Hvað einkennir skapandi kennsluhætti níu tungumálakennara í framhaldsskólum?

a. Finnst kennurunum mikilvægt að ýta undir sköpunarhæfni nemenda sinna og pá hvers vegna?

b. Hvers konar kennsluaðferðum beita peir til að auka sköpunarkraft nemenda sinna?

2. Hvað stendur að peirra mati í vegi fyrir pví, ef eitthvað er, að peir beiti skapandi aðferðum?

\section{Gagnaöflun og pátttakendur}

Rannsóknin byggist á ellefu viðtölum við níu kennara, par sem tekin voru tvö viðtöl við tvo peirra, og eru níu vettvangsathuganir hjá sömu kennurum hafðar til hliðsjónar, ein hjá hverjum kennara. Kennararnir níu eru allir konur, enda er mikill meirihluti tungumálakennara á Íslandi konur. Dær starfa 1 átta misstórum framhaldsskólum, bæði bóknámsskólum og verknámsskólum, á höfuðborgarsvæðinu og á landsbyggðinni, og kenna pær dönsku, ensku, frönsku, spænsku og pýsku. Pátttakendum eru gefin gervinöfn svo ekki sé unnt að rekja frásagnir til peirra. Sjö viðtöl og sjö vettvangsathuganir eru hluti af rannsókninni Starfshættir í framhaldsskólum. [1] Gagna í peirri rannsókn var aflað á árunum 2013 og 2014. Síðan tók höfundur fjögur viðtöl að auki og bætti við tveimur vettvangsathugunum. Pau viðtöl voru tekin á tímabilinu október 2014 til febrúar 2015. Áhugavert var og gagnlegt að geta borið saman viðtöl og vettvangsathuganir pví að pannig fékkst gleggri mynd af pví hvaða augum kennararnir líta skapandi starfshætti og hvernig peir birtast í starfi peirra.

Í viðtölunum sem tekin voru í rannsókninni Starfshættir í framhaldsskólum fylgdu rannsakendur tilteknum viðtalsramma hjá öllum viðmælendum en spurningum var pó breytt eða öðrum spurningum bætt við eftir aðstæðum og voru viðtölin pví hálfopin (Lichtman, 2013). Viðtölin tóku prír rannsakendur. Pátttökuskólar voru valdir á pann hátt að allir framhaldsskólar landsins voru flokkaðir eftir stærð, gerð og staðsetningu. Var tilgangurinn að tryggja sem mesta fjölbreytni og er pví úrtakið lagskipt tilviljunarúrtak. Síðan fór fram útdráttur úr flokkunum og voru níu skólar heimsóttir. Í vettvangsheimsóknunum voru dregin nöfn bekkja eða nemenda af handahófi af öllum námsárum og peim fylgt eftir yfir skóladaginn. Deir kennarar sem viðtöl voru tekin við voru einnig valdir af handahófi úr hópi peirra sem heimsóttir voru. Vegna pess að ekki var hægt að fá svör við öllum peim spurningum sem sérstaklega snúa að skapandi kennsluháttum, pótt vettvangsathuganir segðu töluvert mikið til um slíkt, voru tekin fjögur viðtöl til viðbótar og voru viðmælendur valdir eftir hentugleika. Tekin voru ítarlegri viðtöl við tvo af kennurunum, sem báðir hafa áhuga á skapandi kennsluháttum, og bætt við tveimur viðtölum við kennara sem einnig hafa áhuga á slíkum kennsluháttum, öðrum úr skóla sem styður slíka kennslu og hinum sem starfar í skóla sem ekki leggur sérstaka áherslu á að nemendur fái tækifæri til sköpunar. Í peim viðtölum 
var viðtalsramma fylgt sem nær yfir helstu pemu sem tengjast rannsóknarspurningunum og voru pau viðtöl einnig hálfopin. Tvö peirra voru tekin við tungumálakennara í nýlegum skólum og tvö við kennara í stærri og rótgrónari skólum. Pátttakendur höfðu mislanga starfsreynslu, frá fjórum upp í prjátíu ár.

\section{Greining gagna}

Greining gagnanna byggist á almennri nálgun (e. generic approach) (Lichtman, 2013). Nótur voru flokkaðar út frá peim pemum sem fram koma í rannsóknarspurningunum og við greininguna komu fram undirpemu. Gögnin voru pannig notuð til pess að öðlast skilning á pví hvað einkennir viðhorf níu tungumálakennara í framhaldsskólum til sköpunar í námi og kennslu, hvort peir sjá ástæðu til að leyfa nemendum sínum að vera skapandi og pá hvers vegna, hvers konar kennsluaðferðum peir beita og hvað pað er sem stendur í vegi fyrir pví að peir velji skapandi aðferðir, ef eitthvað er.

\section{Niðurstöður}

Dessum kafla er skipt í prennt og byggjast kaflarnir og undirkaflarnir á premur meginflokkum sem tengjast rannsóknarspurningunum og pemum sem urðu til við greiningu. Fyrsti flokkurinn fjallar um pær kennsluaðferðir sem viðmælendunum finnst helst stuðla að tækifærum til sköpunar, annar flokkurinn fjallar um mikilvægi skapandi kennsluhátta og sá priðji um pað sem helst sem kemur í veg fyrir skapandi kennsluhætti viðmælendanna níu.

\section{Kennsluaðferðir}

Viðmælendurnir notuðu flestir, að sögn, fjölbreyttar kennsluaðferðir. Misjafnt var pó hversu mikinn áhuga peir sögðust hafa á að nota aðferðir sem gefa nemendum tækifæri til að vera skapandi og misjafnt er hversu tilbúnir peir eru að slaka á taumnum og láta nemendur finna eigin leiðir í náminu.

\section{Fjölbreytt tjáning}

Samkvæmt viðmælendunum fá nemendur peirra tækifæri til að tjá sig skriflega á mjög fjölbreyttan hátt. Aðalheiður, Ellen og Júlía sögðust allar pjálfa nýjan orðaforða með pví að láta nemendur skrifa stutt samtöl sem peir leika eða jafnvel taka upp á myndband. Einnig væru smásögur notaðar á skapandi hátt. Aðalheiður og Júlía sögðust láta nemendur sína búa til nýjan endi á smásögur og Aðalheiður sagðist láta sína nemendur búa til nútíma útfærslu af klassískum ævintýrum. Einnig minntist Júlía á stuttar smásögur, örsögur og ljóð sem nemendur hennar skrifa auk pess sem peir tjá skoðanir sínar í dagbók. Viðmælendurnir gáfu dæmi um fleiri tegundir af skriflegum verkefnum. Nefndu Aðalheiður, Karen og María til dæmis fréttagreinar og teiknimyndasögur og Aðalheiður Ellen og María sögðust láta nemendur sína búa til bæklinga og veggspjöld. Loks má nefna að Karen sagðist varpa fram hugmyndum á Facebook sem nemendur síðan tjá sig um.

Nemendurnir tjá sig einnig með myndlist. Aðalheiður sagðist til dæmis láta nemendur sína teikna inn á landakort myndir sem tengjast landi sem unnið er með og myndskreyta smásögur. Einnig notar hún leikinn „Pictionary“ til að pjálfa orðaforða, en pá teikna nemendur orð og aðrir nemendur reyna að giska á hvert orðið er. María gaf einnig dæmi um pað hvernig tungumálanám og myndlist getur farið saman. Hún lætur nemendur sína teikna hús og húsgögn inn í hvert herbergi. Síðan vinna nemendur tveir og tveir saman, annar lýsir húsinu sínu en hinn teiknar upp húsið samkvæmt peim leiðbeiningum sem hann fær. Nemendur hennar og nemendur Aðalheiðar teikna einnig myndasögur og nemendur Júlíu myndskreyta smásögur sem peir lesa. 
Viðmælendurnir gáfu dæmi um pað hvernig hægt er að nota leikræna tjáningu í tungumálanámi. María sagði til dæmis frá hlutverkaleik sem er til pess fallinn að pjálfa orðaforða sem tengist verslunum. „Opnaðar“ eru verslanir og fá nemendur раð hlutverk að vera afgreiðslufólk og viðskiptavinir í mismunandi verslunum. Pannig eru orð sem nemendur eru að tileinka sér pjálfuð á meðan peir spila af fingrum fram. Aðalheiður og Heiða gáfu dæmi um sambærilega hlutverkaleiki sem tengjast veitingahúsum og hótelum og sagði Aðalheiður að slíkir leikir hefðu reynst vel. Júlía notar hlutverkaleik á annan hátt, eða í formi hraðstefnumóts. Nemendur skapa persónur heima og eiga að tala við aðra nemendur í pví hlutverki sem peir sköpuðu. Voru kennararnir fjórir sammála um pað að hlutverkaleikur væri gagnleg leið til að pjálfa tal og nýjan orðaforða og að hann yki áhuga nemenda. Önnur dæmi um leikræna tjáningu sem viðmælendurnir nefndu eru leikurinn „Actionary“ sem Aðalheiði finnst gagnlegur, en pá leika nemendur orð sem peir eru að tileinka sér. Aðalheiður, Júlía og Karen sögðu frá leikritum sem nemendur peirra semja og flytja og stuttmyndum sem peir búa til. Loks má nefna að Karen sagðist gefa nemendum sínum tækifæri til að elda mat og vinna pannig með orðaforða sem tengist ýmsum matartegundum.

Má pví segja að tjáningarform nemendanna séu mjög fjölbreytt og bjóði upp á tækifæri til sköpunar. Eftir situr samt sú spurning hversu stórum hluta af tíma nemenda er varið í slík verkefni pví einungis sást eitt dæmi um slík verkefni í vettvangsheimsóknum. María vann par með pátíð sagna á pann hátt að nemendur fengu nokkur orð á miða sem tengdust sögu sem peir höfðu lesið. Verkefni peirra var að endursegja söguna í pátíð og purftu peir að spinna í kringum pað sem stóð á miðanum par til sagan var sögð. Einnig má nefna að Heiða hvatti nemendur sína til að vera „kreativ” á munnlegu prófi sem var í vændum og tók sem dæmi að peir mættu rappa í prófinu.

\section{Umræður í tungumálanámi}

Umræður henta einstaklega vel í tungumálanámi, sérstaklega í efri áföngum, pví pær gefa nemendum færi á að tjá sig á markmálinu og æfa nýjan orðaforða um leið og peir rökstyðja skoðanir sínar og hlusta á skoðanir annarra. Kom pví á óvart hversu lítið viðmælendurnir virðast nota pá aðferð, og var hún ekki notuð í peim kennslustundum sem vettvangsathuganirnar tóku til. Pó gáfu nokkrir viðmælendanna áhugaverð dæmi um slíkt. Júlía gaf dæmi um málping og Aðalheiður og Ellen sögðu frá hraðstefnumóti, en pá er fólki sem hefur markmálið að móðurmáli boðið í heimsókn. Рað situr við borð, líkt og á hraðstefnumóti, og ganga nemendur á milli og spjalla um fyrirfram ákveðið pema.

\section{Sjálfstæð, skapandi viðfangsefni og áhugasviðsverkefni}

Eftir pví sem ofar dregur í náminu sögðust viðmælendurnir leyfa nemendum meira val um verkefni, bæði hvað snertir inntak og aðferðir, og gáfu fimm peirra dæmi um skapandi áhugasviðsverkefni í lokaáfanga. Misjafnt er pó hversu frjálsar hendur nemendur peirra hafa. Aðalheiður og María gáfu dæmi um verkefni með fyrirfram ákveðinni afurð sem voru annars vegar myndband og hins vegar tímarit. Í myndbandinu unnu nemendur út frá ákveðnu pema og purftu að taka prjú viðtöl en höfðu frjálsar hendur með annað sem peir vildu að fram kæmi í myndbandinu. Viðtölin voru annaðhvort tekin upp á markmálinu eða á íslensku, en pá purftu nemendur að texta pau. Tímaritið er samstarf nemenda, sem koma sér saman um hvers konar greinar peir vilja skrifa í pað og hvað annað peir vilja hafa í pví, eins og til dæmis auglýsingar, myndskreytingar og ljósmyndir. Peir mega pó ekki nota Netið til að afla sér upplýsinga, heldur purfa að finna aðrar leiðir og reynir pað á hugmyndaauðgi peirra. Hugmyndin er að nemendur notfæri sér pá færni og pekkingu sem peir hafa aflað sér í tungumálinu:

Detta er síðasti áfanginn og pess vegna reynum við að hafa pað svona, að pau geti notað tungumálið og áhuga sinn til að gera eitthvað skapandi.

Júlía sagðist ganga enn lengra og leggja fyrir nemendur sína verkefni par sem einu fyrirmælin væru að verkefnið pyrfti að tengjast brautinni, heimildir byrftu að vera traustar og nemendur fengju tvær mínútur til að kynna verk sitt. Karen gaf einnig dæmi um slíkt verkefni: 
Dau máttu velja sjálf hvað pau áttu að gera. Dað voru nokkur skilyrði. Бað átti að vera á markmálinu, helst eitthvað munnlegt og mátti gjarnan vera einhver afurð úr pví.

Ellen gaf dæmi um verkefni sem unnið var með leiðbeinanda, líkt og í háskóla. Petta er verkefni sem kennarinn veit ekki fyrirfram hvert leiðir eða hver útkoman verður pví ekki er stefnt að ákveðinni lausn. Nemendur funda með kennaranum og fá algjört val um viðfangsefnið og reynir á að peir séu hugmyndaríkir og velji verkefni út frá áhugasviði: „Að vinna með leiðbeinanda og fá svona, kasta fram og til baka og pið vitið, svoleiðis, sem er náttúrulega tilgangurinn með pessu." Afurðirnar voru mjög fjölbreyttar, svo sem handbók fyrir ferðamenn, pýðing á smásögu og barnabók sem nemendur skrifuðu og myndskreyttu. Viðmælendunum finnst pessi sjálfstæðu, skapandi verkefni reyna mikið á hugmyndaauðgi nemenda, gagnrýna hugsun peirra og sjálfsaga pví peir purfa að finna sínar eigin leiðir í gegnum pau.

\section{Mótun viðhorfs og gildismats}

Viðmælendurnir gáfu dæmi um pað að peir pjálfuðu nemendur í að horfa gagnrýnum augum á viðteknar hefðir í samfélaginu og hjálpuðu peim að móta sín eigin viðhorf og verða víðsýnni. Júlía sagðist gjarnan velja efni sem ,ýtir við nemendum“ og „skiptar skoðanir eru á“ með pað í huga að „,víkka út sjóndeildarhring nemenda og vinna gegn fordómum“. Aðalheiður og Ellen sögðust einnig velja efni sem væri til pess ætlað að vinna gegn fordómum og bæði Ólöf og Stefanía gáfu dæmi um námsefni sem var sérstaklega valið með pað í huga að ræða jafnrétti. Einnig má nefna аð Karen og María sögðust vinna með menningarlæsi. Pannig opna viðmælendurnir leiðir fyrir nemendur sína til að horfa gagnrýnum augum á viðteknar venjur og gera til peirra ýmsar kröfur sem reyna á gagnrýna hugsun peirra.

\section{Verk nemenda gerð sýnileg}

Misjafnt er hvort viðmælendurnir leggja áherslu á að nemendur kynni verkefni sín fyrir samnemendum sínum, skólanum í heild eða jafnvel að pau séu sýnd öðrum en peim sem tengjast skólanum beint. Algengast er að verkefni séu kynnt inni í kennslustofunum og pá er ýmist um munnlegar kynningar að ræða eða að veggspjöld eru hengd upp. Júlía nefndi einnig að nemendur hennar læsu fyrir samnemendur sína sögur sem peir skrifuðu og lékju frumsamin leikrit. Sáu rannsakendur einmitt dæmi um að verkefni nemenda væru hengd upp í skólastofum eða á göngum skólans. Í kennslustofunni hjá Heiðu mátti sjá vegg pakinn slíkum verkum og notaði hún pau í kennslunni. Hún benti t.d. á pau til að minna nemendur á atriði sem peir höfðu unnið með áđur. María og Karen gáfu dæmi um að verk væru sýnd á netinu, bæði í sérstökum forritum eins og „Photo Story“ og einnig á „Facebook“, og peim deilt með samnemendum. Einnig gaf Aðalheiður dæmi um að verkefni eins og leikrit og myndbönd væru kynnt á sal skólans og væri pá bæði nemendum og kennurum skólans, skólastjórn og foreldrum boðið að koma og sjá, og í einhverjum tilfellum hefðu pau jafnvel ratað í fjölmiðla. Dar að auki bjóða tveir skólanna upp á opið hús fyrir gesti og gangandi par sem verk nemenda eru sýnd og hefur slíkt verið vel sótt. Viðmælendurnir eru sammála um pað að séu skapandi verk nemenda gerð sýnileg leggi peir meiri metnað í pau.

\section{Námsmat}

Námsmat er ólíkt hjá viðmælendum og pótt sumir peirra séu í kapphlaupi við að „komast yfir“ ákveðið efni til lokaprófs pá sögðust aðrir gefa sér tíma til að huga að fjölbreyttara námsmati. Drír viðmælendanna sögðust meta sköpunarpáttinn sérstaklega. Aðalheiður gaf dæmi um munnlegt próf sem er í samtalsformi og sagði að með pví að meta sköpunarpáttinn, pótt hann hafi ekki mikið vægi, verði verkefnið meira krefjandi:

Dau fengu líka gefið fyrir petta, að vera skapandi. Pau meira að segja hálf léku petta í prófunum og pá voru pau föst í hlutverkum. Og petta reyndi miklu meira á pau. 
Júlía gaf einnig dæmi um smásögu sem nemendur hennar skrifa. Í námsmati taka pessir kennarar tillit til tveggja af peim páttum sem Lucas og félagar (2013) setja inn í sóknarkvarðann, p.e. peir meta hversu hugmyndaríkir og samvinnufúsir nemendurnir eru. Deir sögðust líka láta nemendur sína sjálfa meta vinnu sína að einhverju leyti, en mismikið pó og má pví segja að priðji pátturinn, komi parna til, hversu agaðir peir eru. Kennurunum finnst sjálfsmatið meðal annars pjálfa nemendur í að skoða nám sitt á gagnrýninn hátt og velta fyrir sér hvernig peir geti bætt pað auk pess sem slíkt mat og jafningjamat sé mikilvægt pví pað reyni á gagnrýna hugsun og stuðli að sjálfstæði nemendanna. Að lokum má nefna að Aðalheiður sagði frá paraprófi sem reynir á gagnrýna hugsun nemenda pví peir purfa að ræða sín á milli hver besta lausnin sé og rökstyðja svör sín.

\section{Mikilvægi skapandi aðferða}

Viðmælendurnir töluðu margir um mikilvægi pess að gefa nemendum tækifæri til að vera skapandi. Fannst peim nemendur meðal annars verða áhugasamari og ánægðari í námi sínu og trúðu pví að peir yrðu betur búnir undir að mæta peim áskorunum sem biðu peirra í framtíðinni.

\section{Áhugasamari og ánogðari nemendur og kennarar}

Í viðtölunum kemur fram að pegar nemendur fást við skapandi verkefni sem gera peim kleift að fara eigin leiðir pá verði peir bæði áhugasamari og virkari en pegar peir eru mataðir og hafa ekkert um nám sitt að segja. Minntust nokkrir viðmælendanna til dæmis á að orðaforðavinna gæti reynst nemendum erfið og leiðigjörn en Júlía benti á að með pví að nota skapandi aðferðir, eins og til dæmis hlutverkaleik eða málstofu, yrðu nemendur áhugasamari. Hún sagðist finna „áberandi mun á áhugahvötinni“. Karen tók í sama streng og sagði:

Dau hafa meiri áhuga. Dað er alltaf einhver, sama hvað pú gerir, sem hafa ekki rosa mikinn áhuga, en pað eru kannski fleiri sem hafa áhuga, sem klára eitthvað svona verkefni sem pau eru ánægð með heldur en að gera bara eitthvað venjulegt.

Aðalheiður velti pví fyrir sér hvort skapandi aðferðir skiluðu árangri og sagði að pær skiluðu a.m.k. ánægju:

Detta skilar peim kannski að minnsta kosti peirri ánægju að pað er bara ýmislegt að gerast í faginu, pað er pó gaman að vera í tímum og pað er kannski alveg pess virði að gera ýmislegt til pess að halda peim, ekki síst par sem maður er að berjast við priðja tungumálið.

Ólöf minntist einnig á skapandi verkefni í tengslum við áhugahvötina og sagði: „pað parf að hvetja nemendur áfram ef peir eru áhugalausir, nota meira skapandi aðferðir“" og María sagði: „Ég finn áberandi mun á áhugahvötinni, pau gera petta, pau skila frekar ef pað er eitthvað val.“ Aðalheiður benti á hversu hvetjandi slík verkefni eru, ekki síst fyrir slakari nemendur, pví peir fá tækifæri til að nýta hæfileika sem peir hafa á öðrum sviðum:

Og stundum meira að segja eru pað kannski slakari nemendur sem eru verulega góðir í teikningu eða einhverju slíku og geta pá fengið „vá hvað petta er flott hjá pér“ og fá aðeins að njóta sín og fá svolítið pepp sem pau hafa kannski ekki fengið.

Einnig minntist hún á að nemendur pjáđust margir af námsleiða og væru skapandi aðferðir, eins og til dæmis vinnsla stuttmynda eða myndskreytingar verkefna pví nauðsynlegar sem einhvers konar „,uppbrot“. Dótt misjafnt sé hversu mikla áherslu viðmælendurnir leggja á skapandi verkefni eru peir sammála pví að pau auki áhuga nemenda á námsefninu.

Skapandi aðferðir skipta ekki aðeins máli fyrir nemendur heldur einnig fyrir kennara pví slík verkefni gera starf kennaranna áhugaverðara. Karen sagði til dæmis: „Innra með mér er einhver 
pörf fyrir að gera eitthvað skapandi úr pví sem ég er að gera, annars finnst mér bara leiðinlegt.“ Afrakstur skapandi verkefna getur pannig aukið starfsánægju kennara. Júlía var sammála og talaði um að á meðan skapandi aðferðir skiluðu nemendum miklu pá gerðu slíkar aðferðir starf hennar í leiðinni skemmtilegra pví nemendur yrðu virkari. Hún kvað fast að orði:

Dví meira sem við mötum pau pá verða pau svo ótrúlega „passive“ og mér finnst pað mjög sorglegt. Рað að vera með bekk, pú veist, sem horfir bara og bíður. Mér finnst pað alveg hryllilegt.

Dví virðist sem sem skapandi kennsluhættir auki ekki einungis áhuga nemenda á námi sínu heldur einnig kennara á starfinu.

\section{Veganesti út í lífið}

Viðmælendurnir bentu á að skapandi verkefni hjálpuðu nemendum ekki aðeins að tileinka sér tungumálið heldur lærðu peir ýmislegt annað í leiðinni sem nýttist peim í lífinu og hjálpaði peim að takast á við áskoranir framtíðarinnar. Aðalheiður orðaði pað pannig að peir lærðu ,allt önnur vinnubrögð“. Viðmælendurnir sögðu að í slíkum verkefnum væru gjarnan gerðar pær kröfur að nemendur séu sjálfstæðir, hugsi á gagnrýninn hátt, sýni frumkvæði og taki eigin ákvarðanir pegar peir byggja verkefni jafnvel upp frá grunni. Pannig pjálfist peir í að finna lausnir, rökstyðja skoðanir sínar, hlusta á ólík sjónarmið og miðla upplýsingum á skapandi hátt. Í leiðinni öðlist peir hæfni sem nýtist peim í framtíðarstörfum peirra pví peir öðlist aukið sjálfstraust, verði sjálfstæðari og víðsýnni auk pess sem peir pjálfist í samskiptum. Orð Júlíu eru lýsandi fyrir pessa skoðun:

Ég held að framtíðin sé fjölbreytileiki og ég held að pau hafi gott af pví sem undirbúning undir framtíðina og atvinnulífið, taka svolítið ábyrgðina sjálf.

Hún minntist einnig á að sjálfstraust nemenda ykist:

Dau öðlast rosalegt sjálfstæði, bæði í vali á verkefnum, pau trúa á sig og treysta á að pað sem pau eru að segja sé bara í lagi. Dau allt í einu treysta pví að pau geti sagt eitthvað og haft áhrif.

Maríu finnst einnig sjálfstraust nemenda aukast við að glíma við skapandi verkefni og sagði: „Detta eflir líka sjálfstraustið hjá peim, að gera eitthvað fínt á fjölbreyttan hátt.“ Hún sagðist leggja mikla áherslu á að nemendur pjálfuðust í að tala tungumálið og hún notar aðferðir sem líkja eftir pví sem peir geta „lent í “í lífinu. Pannig pjálfist nemendur í samtölum sem séu einhvers konar spuni pví í lífinu séu peir ekki fyrirfram búnir að ákveða hvað peir ætli að segja. Varð rannsakandi einmitt vitni að slíku verkefni, eins og greint er frá í kaflanum Fjölbreytt tjáning. Virðast kennararnir ekki vera bundnir við að kenna einungis sitt fag heldur sjá peir pað einnig sem sitt hlutverk að hjálpa nemendum að próa með sér ýmsa hæfni sem nýtist peim í framtíðinni.

Loks má nefna að áhugavert var að sjá hvernig Heiða vann með námsaðferðir (e. learner strategies) í peirri kennslustund sem rannsakendur sóttu hann heim. Hún spurði nemendur sína ítrekað „hvernig ætlið pið að læra petta?“ Hún lét sem sagt nemendur sína velta pví fyrir sér hvaða aðferðir hentuðu hverjum og einum best, nemendurnir purftu að leggja höfuð í bleyti og koma sjálfir með lausn í stað pess að vera mataðir.

\section{Hindranir sem hægt er að yfirstíga}

Viðmælendurnir níu leggja mismikla áherslu á skapandi kennsluhætti og sumir peirra myndu vilja auka hlut sköpunar í kennslu sinni en ýmis ljón eru á veginum. Nefna peir meðal annars tímaskort, menningu innan skólanna og erfiðleika við að færa vald yfir til nemenda. 


\section{Skapandi verkefni geta verið tímafrek}

Eitt af pví sem viðmælendurnir töluðu um er skortur á tíma til undirbúnings og samstarfs. Ólöf sagði til dæmis:

Við tökum svo ofboðslega mikið af verkefnum með heim og pá fer svo mikill tími í að fara yfir að maður bara eiginlega, bara nær varla að undirbúa sig vel.

Hún talaði einnig um mikilvægi samstarfs og sagði: ,við fáum jafnvel ráð hvert hjá öðru, ef pað gefst tími til pess.“ Dar að auki nefndu nokkrir viðmælendanna pað hversu tímafrek skapandi verkefni eru. Kennarinn parf gjarnan að búa sjálfur til slík verkefni í stað pess að nota æfingar sem fyrir eru í kennslubókum og pannig eykst vinnuálag hans. Aðalheiður benti á að pað að láta nemendur fylla inn í eyður eða tengja saman orð tekur skemmri tíma en að láta pá vinna með orðaforða á skapandi hátt, til dæmis með pví að nota hann í hlutverkaleik. Júlía nefndi einnig tímaskort og sagði að ef hún vildi bjóða upp á fjölbreytt verkefni kostaði pað ,,aukavinnu“. Баð sama ætti við um yfirferð verkefna. Aðalheiður sagðist vilja tvinna meira saman orðaforðavinnu og skapandi aðferðir en hafði áhyggjur af pví að pá myndi ekki ganga nógu vel að „komast yfir" námsefnið og pví sæeti slík vinna á hakanum. Má pví segja að togstreita geti myndast hjá kennurum sem eru sannfærðir um að ein aðferð sé betri en önnur en gefa sér prátt fyrir pað ekki tíma til að nota hana. Ákveðnar vísbendingar má pví sjá pess eðlis að kennararnir séu ekki nægilega lausnamiðaðir við að finna leiðir til að vinnan við að framkvæma skapandi verkefni verði ekki meiri en með hefðbundnum verkefnum eins og eyðufyllingarverkefnum. Pó má nefna að ýmsar lausnir eru á pessu vandamáli. Aðalheiður benti á mikilvægi pess að kennarar auki samvinnu sín á milli, til dæmis með pví að deila verkefnum og María talaði um mikilvægi pess að endurmenntun væri alltaf hluti af starfi kennarans ,svo ekki purfi að verja frítíma í að próa nýjar leiðir í kennslunni“.

\section{Skólamenning}

Ýmislegt í menningu skóla getur bæði stuðlað að og komið í veg fyrir að kennarar leggi skapandi verkefni fyrir nemendur sína. Áberandi er að skólastjórnendur gefa kennurum lausan tauminn og sýna peim traust. Sagði Fríða til dæmis pegar rætt var um skólastjórnendur: „Okkur er fullkomlega treyst sem fagmönnum hérna,“ og Karen sagði: „Ég get farið mínar eigin leiðir og gert í raun og veru pað sem mig langar til." Skólastjórnendur virðast almennt ekki setja kennurum skorður en styðja hins vegar almennt ekki við bakið á peim sem vilja próa nýjar leiðir. Pó nefndi Júlía að í hennar skóla væri stefnan sú að hlúa að sköpunarpættinum og væri hún hvött til pess.

Ákveðnar hefðir geta ríkt í skólunum eða deildum innan skólanna sem erfitt er að brjótast út úr. Aðalheiður nefndi til dæmis ákveðnar kennsluaðferðir sem tíðkast að nota og stórt lokapróf í lok annar sem stýrir kennslunni. Fríða tók fram að pað væri stefna skólans að vera með lokapróf og Ólöfu fannst próf jafnvel notuð sem einhvers konar agatæki:

Баð er alltaf pessi hótun að pað verði einhvers konar próf og pau læra frekar fyrir pað af pví að pau vita að pau annars kannski falla.

Einnig minntist Aðalheiður á að kennslubækur stjórnuðu miklu. Hún var ekki hrifin af kennslubókinni sem hún notar:

Раð mætti uppfæra hana með pínulítið meiri sköpun og skemmtilegri verkefnum. Mér finnst petta vera of mikið bara orðaforði og fylla í eyður.

Heiða talaði einnig um að kennslubókin stjórnaði, en hún er byggð upp með pað að markmiði að ná ákveðnu stigi í tungumálarammanum:

Dannig að við vitum að ef að pau ná að klára pessa tíu kafla að pá í lok prófsins erum við búin að ná markmiðunum. 
Dar að auki minntust bæði Aðalheiður og Ólöf á pað að hefð væri fyrir stífum námsáætlunum sem kæmu í veg fyrir að pær legðu skapandi verkefni fyrir nemendur sína. Við gerð námsáætlana er ekki gert ráð fyrir slíkum verkefnum. Aðalheiður hafði áhyggjur af pessu og sagði:

Maður veit alveg að um leið og maður fer að leyfa peim ýmislegt svona pá er pessi spurning í raun yfirferð á námsefni. Ég verð að koma peim yfir námsefnið fyrir annarlok.

Dannig getur ofhlaðin námsáætlun stýrt kennslunni og getur kapphlaupið við að ná að ljúka yfirferð námsefnis jafnvel alveg hindrað að hægt sé að leggja skapandi verkefni fyrir nemendur. Námsefnið virðist pá ráđa ferðinni fremur en hæfniviðmið námskrár. Karen benti á að stærð skóla skipti máli í pessu samhengi, að auðveldara væri að sníða námsáætlun að skapandi kennsluháttum í minni skólum. Sagði hún sem dæmi um pað að nemendur hennar tækju jafnvel pátt í að semja námsáætlunina. Dá minntust prír viðmælendur á að par sem ekki væri hefo fyrir pví að meta skapandi verkefni væru peir óöruggir og vissu ekki hvernig peir ættu að gera pað. Ólöf gekk svo langt að segja að petta væri pað flókið að best væri að sleppa pví. Loks má nefna að í sumum tilfellum er ekki mikil hefð fyrir pví að kennarar vinni saman að próun kennsluhátta. Sýnir petta mikilvægi pess að kennarar vinni pétt saman og hafi í huga við samningu námsáæetlana hvers konar aðferðum peir vilja beita, að peir einblíni ekki einungis á námsefnið heldur líka hæfniviðmið.

\section{Óttinn við óreiðuna}

Eitt af pví sem getur komið í veg fyrir að kennarar leggi skapandi verkefni fyrir nemendur sína er að erfitt getur verið fyrir pá að hafa ekki fulla stjórn á pví sem fram fer í kennslustundinni. Ólöf sagðist til dæmis líta á sig sem stjórnanda og að nemendum liði vel í slíku umhverfi og ennfremur að peir væru ekki í stakk búnir til að velja námsefni sjálfir: „Đau eru ekki komin með pann proska að pau fari að koma með hugmynd аð pema eða neinu svoleiðis." Í skapandi verkefnum fara nemendur gjarnan að einhverju leyti eigin leiðir, en pað pýðir að kennarar purfa að slaka á taumnum og læra að treysta nemendum sínum og nemendur burfa að fá að venjast frelsinu sem fylgir breyttum kennsluháttum.

Nemendur geta orðið óöruggir pegar kemur að pví að vinna á skapandi hátt ef peir eru ekki vanir pví. Gáfu viðmælendur nokkur dæmi um slíkt og sagðist Aðalheiður fá spurningar eins og „,getum við ekki fengið meira svona venjulega kennslu?“ og „,geturðu ekki bara kennt okkur svona upp á töflu?“. Júlía sagðist hafa fengið spurninguna „geturðu ekki bara sagt mér hvað ég á аð gera?“. Ólöf upplifir svipað í sinni kennslu, og pegar hún var innt eftir pví hvernig gengi að láta nemendur vinna á skapandi hátt sagði hún: „Đau vilja helst eiginlega gera sem minnst af pví. Dau vilja kannski læra einhverjar staðreyndir.“ Einnig var talað um að ef nemendur fengju lausan tauminn gæti peim fundist að kennarinn sinnti ekki skyldu sinni. Aðalheiður gaf dæmi um slíkt: „Degar við gefum peim of mikið svona lausan tauminn pá hafa pau stundum á tilfinningunni að við séum ekkert að kenna." Júlía upplifir pað að nemendum geti hreinlega „fallist hendur“ og peim geti fundist erfitt að hugsa út fyrir hinn hefðbundna ramma:

Раð eru alltaf sumir sem eru rosalega fastir í einhvern svona kassa. Dú veist, maður parf að hjálpa peim að hugsa. Dú veist, pað er allt í lagi að vera fastur í kassanum en geturðu gert eitthvað í pví, breytt pví til að gera öðruvísi?

Hún bendir á að pó að nemendum geti reynst erfitt að venjast nýjum vinnubrögðum pá sé pað hlutverk hennar að breyta pví. María upplifir einnig óöryggi nemenda: „Fyrst eru pau svolítið týnd og pau segjast ekki kunna svoleiðis.“ María segir líka að nemendum hennar finnist stundum erfitt að átta sig á pví hvað pað sé að vera skapandi og hvað peir eigi að gera pegar hún biður pá að „fara ótroðnar slóðir“. Svo má nefna að Júlía segir að nemendum finnist oft erfitt að trúa pví að ekki sé til eitt rétt svar við verkefnum. Skapandi verkefni geta bví reynst vera áskorun fyrir nemendur, eins og kennara, og mikilvægt er að kennarar sýni nemendum sínum skilning og 
útskýri fyrir peim tilgang verkefna. Degar auka á pátt sköpunar purfa nemendur að vera tilbúnir að breyta vinnu sinni og pað er verkefni kennara að fá pá til liðs við sig og gefa peim tækifæri til að kynnast nýjum leiðum sem reyna meira á frumkvæði peirra.

\section{Samantekt og umræða}

Sú menntastefna sem birtist í Ađalnámskrá framhaldsskóla frá árinu 2011 byggist á sex grunnpáttum menntunar og er sköpun einn peirra. Áhugavert er pví að sjá hvaða leiðir tungumálakennarar í framhaldsskólum fara til að gera sköpun að pætti í námi nemenda sinna. Markmið rannsóknarinnar var að komast að pví hvort níu tungumálakennarar sjái ástæðu til að leyfa nemendum sínum að vera skapandi og pá hvers vegna. Einnig var áhugavert að skoða hvers konar kennsluaðferðum peir beita og hvort eitthvað stendur í vegi fyrir pví að peir velji skapandi aðferðir og hvað pað er pá helst.

\section{Sköpun í námi skiptir máli}

Dótt viðmælendurnir virtust ekki allir hafa áhuga á pví að leggja verkefni fyrir nemendur sína sem gæfu peim færi á að vera skapandi, eða gæfu sér ekki tíma til pess, pá voru peir flestir á pví að slík verkefni ykju bæði áhuga nemenda og ánægju (sbr. Trilling og Fadel, 2009). Ein stærsta áskorun hvers kennara er að finna leiðir til að virkja áhuga nemenda á náminu og er pví athyglisvert að kennarar sem hafa fundið slíka leið skuli ekki nýta hana betur. Einnig var athyglisvert að peir viðmælendur sem töldu mjög mikilvægt að gefa svigrúm fyrir sköpun töluðu um að slík vinna yki ekki aðeins áhuga nemenda peirra heldur einnig starfsánægju peirra sjálfra. Dessar niðurstöður eru í samræmi við kenningu Csikszentmihalyi (1996) um að sköpun stuðli að aukinni gleði, og niðurstöður rannsóknar Lamont, Jeffes og Lord (2010).

Nokkrir viðmælendanna töluðu um að skapandi kennsluhættir skiluðu nemendum peirra veganesti út í lífið. Gáfu peir fjölmörg dæmi um pað, eins og að nemendur fengju pjálfun í að hugsa á gagnrýninn hátt, taka ákvarðanir og, líkt og Bamford (2011), Craft (2010), Dam (1998) og Trilling og Fadel, (2009), bentu peir á að peir pjálfuðust í að finna lausnir. Dar að auki fengju peir tækifæri til að styrkja hæfileika sína. Detta fannst viðmælendunum stuðla að auknu sjálfstrausti og sjálfstæði sem gerði pað að verkum að nemendurnir yrðu víðsýnni og pví betur í stakk búnir til að leggja sitt af mörkum til samfélagsins (sbr. Moran og John-Steiner, 2003 og Csikszentmihalyi, 1996). Mikilvægt er pví að kennarar prói saman skapandi kennsluhætti og stuðli pannig að pví að nemendur fái tækifæri til að stunda nám sitt í umhverfi sem styrkir pá og framkallar pað besta í fari hvers og eins.

\section{Kennsluaðferðir sem gefa tækifæri til sköpunar}

Viðmælendurnir gáfu dæmi um fjölbreytt skapandi verkefni pótt ekki væru mörg slík verkefni í gangi í peim kennslustundum sem rannsakendur fylgdust með hjá peim. Má sem dæmi nefna ýmsar tegundir tjáningarverkefna og sjálfstæð, skapandi viðfangsefni par sem nemendur fá að hreyfa sig innan ákveðins ramma sem kennarinn skilgreinir fyrirfram og er ramminn misstífur. Ákveðin stígandi er í slíkum verkefnum pannig að í efstu áföngunum hafa nemendur mesta frelsið, bæði hvað varðar efni og efnistök. Nemendur purfa sjálfir að finna lausnir og eigin leiðir í náminu og ekki er í slíkum verkefnum stefnt að einu réttu svari (sbr. Dewey, 1938/2000 og Eisner, 2002).

Vettvangsathuganir, sem rannsókn pessi byggist að hluta til á, sýna að nám peirra nemenda sem fylgst var með virðist að mestu leyti vera kennarastýrt. Раð er í takt við niðurstöður rannsóknar Gerðar G. Óskarsdóttur (2012). Dar kemur fram að hugmyndaauðgi og sjálfstjórn minnkar pegar nemendur færast úr grunnskóla í framhaldsskóla og er bó ekki stór hluti af námi nemenda í grunnskóla. Æskilegra væri að nemendur hefðu meira um nám sitt að segja pegar peir eldast og 
proskast. Dessi rannsókn sýnir pó að eftir pví sem lengra líður á námið slaknar á taumnum og skapandi verkefnum fjölgar. Auka parf sjálfstæði nemenda strax á fyrsta ári í framhaldsskóla og fjölga par með tækifærum peirra til að vinna að skapandi verkefnum, ekki síst eftir að nám til stúdentsprófs var stytt um eitt ár.

Sumar af peim aðferðum sem viðmælendurnir sögðust beita og pað efni sem peir velja stuðlar að pví að nemendur tileinki sér ákveðin viðhorf eða gildismat. Nemendur pjálfast 1 að horfa gagnrýnum augum á viðteknar hugmyndir í samfélaginu og móta eigin sýn, til dæmis pegar unnið er með jafnrétti og menningu annarra pjóða. Í Aðalnámskrá framhaldsskóla (Menntaog menningarmálaráðuneytið, 2011) kemur einmitt fram að í sköpun felist að nemendur horfi gagnrýnum augum á viðteknar venjur og proski með sér heilbrigð viðhorf.

Allir viðmælendurnir leyfa fleirum en peim sem vinna skapandi verkefni að njóta peirra. Nemendur flytja fyrirlestra sem samnemendur peirra hlýða á og útbúa veggspjöld sem hengd eru upp bæði í stofum peirra og á göngum skólans. Deir flytja sögur sem peir hafa samið og leikrit fyrir bekkinn eða jafnvel á sal skólans og er öðrum nemendum, kennurum og jafnvel foreldrum boðið að koma. Einnig eru pess dæmi að nemendur fái athygli utan veggja skólans og í tveimur skólum er foreldrum og öðrum áhugasömum boðið í opið hús til að skoða afrakstur nemenda. Ĺkt og Bamford (2011) og Dam (1998) líta viðmælendurnir á pað að gera verkin sýnileg sem hluta af sköpunarferlinu, sem hvetji nemendur áfram og auki líkurnar á pví að peir vandi til verka.

Misjafnt er hvort sköpunarpátturinn kemur inn í námsmat en nokkrir viðmælendanna meta sköpunarpáttinn og er sköpun jafnvel undirstaða matsins. Tveir peirra meta til dæmis hversu frumlegir nemendur eru í efnisvali og efnistökum og hvernig peim gengur að vinna með öðrum. Frumleiki og samvinna er einmitt hluti af sóknarkvarða Lucas o.fl. (2013).

\section{Ljón á veginum}

Niðurstöður rannsóknarinnar sýna að mörg ljón eru á veginum pegar kemur að pví að gefa nemendum tækifæri til að vera skapandi. Áhugi viðmælendanna á pví að hlúa að pessum pætti er mismikill en jafnvel peir áhugasömustu standa andspænis hindrunum sem erfitt getur verið að yfirstíga, en pó mögulegt. Ein stærsta hindrunin er yfirhlaðnar námsáæetlanir og lokapróf sem stýra yfirferð námsefnis (sbr. Hafdísi Ingvarsdóttur, 2004, Gerði G. Óskarsdóttur, 2012 og Collard og Looney, 2014). Petta sýnir að ef kennarar vilja efla sköpunarpáttinn í námi nemenda sinna purfa peir að hafa pað í huga strax við gerð námsáætlana pví peir telja að meiri tíma purfi í slíka vinnu en hefðbundið kennarastýrt nám. Mikilvægt er að kennarar gefi sér pann tíma sem peir purfa til að sinna slíkri vinnu og að peir skapi svigrúm til pess að próa ný verkefni. Dað geta peir gert með ýmsum hætti, til dæmis með aukinni samvinnu, með pví að skera niður námsefni, auka sjálfsmat nemenda og í kjölfarið „fara yfir“ færri verkefni. Pær breytingar sem purfa að eiga sér stað til að fjölga skapandi verkefnum eru pví að miklu leyti í höndum kennaranna sjálfra.

Viðmælendurnir nefndu ýmislegt annað sem kemur í veg fyrir að peir leggi skapandi verkefni fyrir nemendur sína. Má par nefna að ekki er hefð fyrir slíkum vinnubrögðum í skólunum sem peir starfa við og peir vita ekki hvernig peir eiga að búa til og meta slík verkefni (sbr. rannsóknir Cizek, 2001; Hamilton o.fl., 2005; Collard og Looney, 2014 og Berland, 2013). Mat á skapandi verkefnum virðist reynast kennurum sérstaklega erfitt, en próaðar hafa verið aðferðir sem geta hjálpað peim að meta slík verkefni og er sóknarkvarði Lucas o.fl. (2013) gott dæmi um slíkt.

Einnig getur óttinn við óreiðuna komið í veg fyrir að kennarar brjóti upp hefðbundna kennslu og losi takið. Peir óttast að vald peirra og aðhald verði ekki nógu gott (sbr. Hafdísi Ingvarsdóttur, 2004; Hjördísi Dorgeirsdóttur, 2018). Líkt og í rannsókn Hafdísar Ingvarsdóttur (2004) leiddu vettvangsathuganirnar 1 ljós a $i_{1}$ flestum kennslustundunum var kennslan kennarastýrð og nemendurnir höfðu lítið um nám sitt að segja. Til að fjölga tækifærum til sköpunar er einmitt nauðsynlegt að kennarar losi takið og læri að treysta nemendum sínum betur. Dam (1998) bendir 
pannig á mikilvægi pess að kennarar treysti nemendum til að taka ákvarðanir. Að sama skapi kunna nemendur að vilja láta mata sig í stað pess að vinna verkefni sem krefjast pess að peir finni eigin leiðir. Баð аð peim finnist gott að halla sér aftur og láta mata sig skýtur skökku við pví samkvæmt pessari rannsókn og fleiri rannsóknum (Trilling og Fadel, 2009; Starko, 2014) eykst áhugi nemenda ef peir fá skapandi verkefni. Í pessu má sjá vissa mótsögn sem áhugavert væri að skoða nánar. Einnig kom á óvart að peir viðmælendur sem ekki gefa nemendum sínum mörg tækifæri til sköpunar kvarta jafnvel undan áhugaleysi peirra, en segja pó að skapandi vinna auki áhuga. Vekur pað upp spurningar um pað hvers vegna peir gefa pá ekki nemendum sínum fleiri tækifæri til að vera skapandi. Dó að umhverfið setji kennurum einhverjar skorður virðast flestar hindranirnar vera sjálfsprottnar og er pað pví að mestu leyti í höndum kennaranna sjálfra að brjóta niður pá múra sem peir hafa sjálfir hlaðið upp.

Kennararnir sjálfir hafa mikið um pað að segja hvort peir auka hlut sköpunar í námi nemenda sinna eða ekki en slíkar breytingar kalla einnig á nauðsynlegan stuðning frá skólastjórnendum (sbr. Collard og Looney, 2014). Deir purfa að styðja við bakið á kennurum og leiða umbótavinnu með skýrri stefnu. Einnig er mikilvægt að peir bjóði upp á námskeið sem hjálpa kennurum að útfæra grunnpáttinn sköpun í kennslu sinni. Kennarar og skólastjórnendur geta með góðri samvinnu próað saman kennsluhætti og stuðlað pannig að pví að nemendur fái tækifæri til að stunda nám sitt í umhverfi sem framkallar pað besta í fari hvers og eins nemanda og gefur tækifæri til sköpunar.

\section{Horft fram á veginn}

Við vinnu pessarar greinar vöknuðu ýmsar hugmyndir um frekari rannsóknir á sköpun í skólastarfi. Áhugavert væri til dæmis að kanna hvort sambærilegar niðurstöður myndu fást ef önnur fög en tungumál yrðu skoðuð. Einnig er mikilvægt að ljá nemendum rödd og skoða hverju peim finnst sköpun í námi peirra skila. Loks væri áhugavert að skoða hvaða áhrif stytting náms til stúdentsprófs hefur haft á tækifæri nemenda til sköpunar.

Баð er von mín að rannsóknin hafi pýðingu fyrir bæði kennara og skólastjórnendur og að hún geti hvatt pá til að auka hlut sköpunar í námi nemenda. Niðurstöður sýna að mikilvægt er að styðja við bakið á kennurum, bæði í námi peirra og endurmenntun, pví kennarar sem stíga út fyrir hinn hefðbundna kennsluramma og gefa nemendum sínum tækifæri til að vera skapandi í námi sínu fá meiri ánægju út úr starfi sínu og nemendur peirra verða í kjölfarið áhugasamari og öðlast margvíslega hæfni sem nýtist peim í lífinu. Рað hlýtur alltaf að vera tilgangurinn að sem flestir nemendur komist til manns með virkri pátttöku í kennslustundum, par sem hugmyndaflug og sköpunargleði fær að njóta sín. Slík vinna skilar án efa sterkari einstaklingum út í samfélagið og pví skiptir sköpun sköpum.

\section{Aftanmálsgrein}

1. Megingagnasöfnun í rannsókninni Starfshættir í framhaldsskólum fór fram á tímabilinu október 2013 til nóvember 2014 í níu framhaldsskólum, auk pess sem rannsóknartækin voru forprófuð í tíunda skólanum. Gögnin eru vettvangslýsingar á 130 kennslustundum, yfir 60 afrituð viðtöl við nemendur (hópviðtöl), kennara og stjórnendur, ljósmyndir úr kennslustofum, kennsluáætlanir og önnur skrifleg gögn. Fimmtán manna hópur fræðafólks við Menntavísindaog Félagsvísindasvið Háskóla Íslands tók pátt í gagnasöfnuninni. Rannsóknin naut styrkja úr Rannsóknarsjóði Háskóla Íslands á árunum 2013-2015og frá Norræna öndvegissetrinu Justice Through Education in the Nordic Countries, styrktu af NordForsk, 2013-2018. Við pökkum sérstaklega framhaldsskólunum sem veittu aðgang að starfinu í rannsóknarskyni. 


\section{Creativity in Language Learning: How language teachers view creative teaching practices}

Being creative is an integral part of being a human. Most people recognise the feeling of joy after engaging in a creative activity and creativity is a force that drives human evolution. Therefore, it is interesting that creativity is one of the six fundamental pillars defined in the national curriculum, which education in upper secondary schools in Iceland is to rest on. It is not hard for language teachers to facilitate creativity in the classroom. Language learning opens doors to endless possibilities since teachers can choose diverse topics and twine them together with any teaching method they like.

The aim of this study was to find out whether nine language teachers in upper secondary schools see reasons to give their students opportunities to be creative and if they do, why. Also, to find out which teaching methods they use and, finally, whether they face any obstacles that prevent them from using creative teaching methods. Creativity is discussed in regard to the ideas presented in the National Curriculum Guide and the report of the National Advisory Committee on Creative and Cultural Education, All our futures: Creativity, culture and education. The subject is also considered in the light of the scholars John Dewey, Lev Vygotsky, Elliot Eisner and Mihaly Csikszentmihalyi. Furthermore, the characteristics of a creative person, a creative learning environment and teaching methods which can foster students'creativity are discussed.

This study is part of the research Upper Secondary School Practices in Iceland and is based on seven interviews and seven classroom observations from that research. Additionally, the researcher conducted four more interviews and made two more field studies. The participants come from eight different upper secondary schools in Iceland.

The main findings show that most of the teachers find it important to foster their students' creativity. Although very few examples were seen of creative work during field studies, the participants give various reasons for the importance of creative teaching methods. They believe that such methods motivate both students and teachers. They also believe that the students become better equipped to meet future challenges, since creative teaching methods encourage them to work independently, practice critical thinking, show initiative, make decisions, find solutions and listen to different points of view. As a result, the students become open-minded and independent, which leads to increased self-confidence.

The nine teachers maintain that they use diverse methods to increase their students' creativity. For example, they give their students opportunities to express themselves through various means, such as creative writing, role play and creative projects. Towards the end of their studies, they give them creative projects through which they can find their own paths, both when it comes to methods and content. They also give examples of a symposium, speed dates and assignments which help students develop an open-minded view. Two of the teachers add that creativity is part of their assessment.

However, certain things prevent them from using those methods as much as they would like to. Among the reasons they cite is lack of time, traditions within the schools which are difficult to change and problems with evaluation. They also mention that changes in their work environment can be challenging. Some of them like to hold the reins and are not ready to hand them over to their students who would not necessarily be ready to hold them. 
The results of the research suggest that in order to take note of the National Curriculum, a creative approach in language studies needs to be stimulated. Student autonomy needs to be encouraged and the leeway for teachers to work together, both within and between departments, increased so that they can develop, creative teaching methods. It is important that school leaders support teachers. Collaboration between teachers, school leaders and people outside the classroom is important to create an environment that gives each student an opportunity to be creative and thrive in an ever-changing society.

Key words: Creativity, motivation, pillars of education, assessment, language learning

\section{Um höfundinn}

Ásta Henriksen (asta@verslo.is) er framhaldsskólakennari viðVerzlunarskóla Íslands. Hún lauk B.A.-prófi í ensku, uppeldis- og kennslufræði til kennsluréttinda og M.A.-gráðu í uppeldis- og menntunarfræði frá Háskóla Íslands. Ásta hefur lengst af kennt ensku við Verzlunarskóla Íslands og tekið pátt ́ ýmsum skólabróunarverkefnum. Fagleg áhugamál hennar lúta m.a. að próun skapandi kennsluhátta með aukinni pátttöku nemenda í eigin námi.

\section{About the author}

Ásta Henriksen (asta@verslo.is) is an upper secondary school teacher at Verzlunarskóli Íslands (The Commercial College of Iceland). She holds a B.A. degree in English, a teaching degree and an M.A. degree in Education Studies from the University of Iceland. During most of her career she has taught English at Verzlunarskóli Íslands where she has participated in various school development projects. Her main interests in teaching include student engagement and creative teaching methods.

\section{Heimildir}

Amabile, T. M. (1979). Effects of external evaluation on artistic creativity. Journal of Personality and Social Psychology, 37(2), 221-233.

Anna Jeeves. (2013). Relevance and the L2 self in the context of Icelandic secondary school learners: Learner views (óútgefin doktorsritgerð). Sótt af http://hdl.handle.net/1946/16755

Bamford, A. (2011). List- og menningarfreðsla á Íslandi. Reykjavík: Mennta- og menningarmálaráduneytið.

Bandura, A. (1977). Self-efficacy: the exercise of control. New York: Freeman.

Berland, E. (2013). Barriers to creativity in education: educators and parents grade the system. Sótt af http://wwwimages.adobe.com/content/dam/Adobe/en/education/pdfs/creativity-study-infographic.pdf

Bowkett, S. (2005). 100+ ideas for teaching creativity (2. útgáfa). London: Continuum.

Brookhart, S. M. (2010). How to assess higher-order thinking skills in your classroom. Alexandria,VA: ASCD.

Cachia, R., Ferrari,A.,Ala-Mutka, K. og Punie,Y. (2010). Creative learning and innovative teaching: final report on the study on creativity and innovation in education in the EU member states. Sótt af http://ftp.jrc.es/EURdoc/ JRC62370.pdf

Cizek, G.J. (2001). More unintended consequences of high-stakes testing. Educational Measurement: Issues and Practices, 20(4), 19-27. doi:10.1111j.1745-3992.2001.tb00072.x

Collard, P. og Looney, J. (2014). Nurturing creativity in education. European Journal of Education, 49(3), 305-450. doi:10.1111/ejed.12090

Craft, A. (2010). Creativity and education futures. Learning in a digital age. Stoke-on-Trent: Trentham Books.

Cropley, A. J. (2001). Creativity in education E learning. A guide for teachers and educators. Abingdon: Routledge.

Csikszentmihalyi, M. (1996). Creativity: Flow and the psychology of discovery and invention. New York: HarperPerennial. 
Dam, L. (1998). Why focus on learning rather than teaching? From theory to practice. Í D. Little, D. Dam og J. Timmer (ritstjórar), Focus on learning rather than teaching: why and how? (bls. 18-37). Dublin: CLCS, Trinity College.

Dewey, J. (2000). Reynsla og menntun (Gunnar Ragnarsson pýddi). Reykjavík: Rannsóknarstofnun Kennaraháskóla Íslands (frumútgáfa 1938).

Edwards, S. M. (2001). The technology paradox: efficiency versus creativity. Creativity Research Journal, 13(2), 221-228. Sótt af http://web.b.ebscohost.com/ehost/pdfviewer/pdfviewer?sid=c63991ff-63a5-4e25-87 be-07a0bbf7368a\%40sessionmgr112\&vid=1\&hid=116

Eisner, E.W. (2002). The arts and the creation of mind. New Haven:Yale University Press.

Gerður G. Óskarsdóttir. (2012). Skil skólastiga: Frá leikskóla til grunnskóla og grunnskóla til framhaldsskóla. Reykjavík: Háskólaútgáfan og Skóla- og frístundasvið Reykjavíkurborgar.

Grant, H. og Dweck, C. S. (2003). Clarifying achievement goals and their impact. Journal of Personality and Social Psychology, 85(3), 541-553. doi:10.1037/0022-3514.85.3.541

Hafdís Ingvarsdóttir. (2004). ,... ef pað er eitthvað sem peim pykir áhugavert.“ Enskukennsla við upphaf 21. aldar. Í Úlfar Hauksson (ritstjóri), Rannsóknir i félagsvísindum V (bls. 471-481). Reykjavík: Háskólaútgáfan.

Hafdís Ingvarsdóttir. (2006). ,... eins og pver geit í girðingu“:Viðhorf kennara til breytinga á kennsluháttum. Í Úlfar Hauksson (ritstjóri), Rannsóknir i félagsvísindum VII (bls. 351-363). Reykjavík: Félagsvísindastofnun Háskóla Íslands.

Hamilton, L. S., Berends, M. og Stecher, B. (2005). Teachers' responses to standards-based accountability. Santa Monica, CA: RAND Corporation.

Hjördís Porgeirsdóttir. (2018). The change room promotes teachers' agency to change their practice. Educational Action Research. doi:10.1080/09650792.2018.1436080

Houtz, J. C. (1990). Environments that support creative thinking. Í C. Hedley, J. Houtz, og A. Baratta,(ritstjórar), Cognition, curriculum and literacy (bls. 61-76). Norwood: Ablex.

Ingibjörg Jóhannsdóttir, Elísabet Indra Ragnarsdóttir og Torfi Hjartarson. (2012). Sköpun - Grunnpáttur í menntun á öllum skólastigum. Reykjavík: Mennta- og menningarmálaráđuneytið og Námsgagnastofnun.

Lamont, E., Jeffes, J. og Lord, P. (2010). Evaluation of the nature and impact of the creative partnerships programme on the teaching workforce. Sótt af https://www.nfer.ac.uk/publications/TWIZ01/TWIZ01.pdf

Lichtman, M. (2013). Qualitative research in education - A user's guide. Thousand Oaks: Sage.

Little, D. (2003). Learner autonomy and second/foreign language learning. Sótt af https://www.llas.ac.uk/resources/ gpg/1409

Lucas, B. (2001). Creative teaching, teaching creativity and creative learning. Í A. Craft, B. Jeffrey og M. Leibling (ritstjórar), Creativity in education (bls. 35-44). London: Continuum.

Lucas, B., Claxton, G. og Spencer, E. (2013). Progression in student creativity in school: First steps towards new forms of formative assessments. doi:10.1787/5k4dp59msdwk-en

Mennta- og menningarmálaráđuneytið. (2011). Ađalnámskrá framhaldsskóla: Almennur hluti. Reykjavík: Mennta- og menningarmálaráðuneyti.

Moran, S. og John-Steiner,V. (2003). Creativity in the making.Vygotsky's contemporary contribution to the dialectic of development and creativity. Í R. K. Sawyer, V. John-Steiner, S. Moran, R. J. Sternberg, D. H. Feldman, J. Nakamura og M. Csikszentmihalyi (ritstjórar), Creativity and Development (bls. 61-86). New York: Oxford University Press.

National Advisory Committee on Creative and Cultural Education [NACCCE]. (1999). All our futures: Creativity, culture and education. Sótt af http://sirkenrobinson.com/pdf/allourfutures.pdf

Starko, A. J. (2014). Creativity in the classroom (5. útgáfa). New York: Routledge.

Sternberg, R. J. og Kaufman, J. C. (2010). Constraints on creativity: obvious and not so obvious. Í J. C. Kaufman og R. J. Sternberg (ritstjórar), The Cambridge handbook of creativity (bls. 467-482). Cambridge: Cambridge University Press.

Svanborg R. Jónsdóttir. (2016). Leikum, lærum, lifum: Námssvið leikskóla og grunnpættir menntunar. Í Kristín Karlsdóttir og Anna Magnea Hreinsdóttir (ritstjórar), Sköpun og skólastarf (bls. 77-94). Reykjavík: RannUng og Háskólaútgáfan. 
Svanborg R. Jónsdóttir. (2017). Narratives of creativity: How eight teachers on four school levels integrate creativity into teaching and learning. Thinking Skills and Creativity, 24, 127-139. doi:10.1016/j.tsc.2017.02.008

Svanborg R. Jónsdóttir og Allyson Macdonald. (2011). Looking at the pedagogy of innovation and entrepreneurial education with Bernstein. Rádstefnurit Netlu - Menntakvika 2011. Sótt af http://netla.hi.is/ menntakvika2011/028.pdf

Timperley, H., Wilson, A., Barrar, H. og Fung, I. (2007). Teacher professional learning and development: best evidence synthesis iteration. Sótt af http://www.educationcounts.govt.nz/_data/assets/pdf_file/0017/16901/ TPLandDBESentireWeb.pdf

Trilling, B. og Fadel, C. (2009). 21st century skills: learning for life in our time. San Francisco: Jossey-Bass.

Ásta Henriksen (2018).

Sköpun skiptir sköpum: Viðhorf tungumálakennara til skapandi kennsluhátta.

Netla - veftímarit um uppeldi og menntun. Sérrit 2018 - Framhaldsskólinn í brennidepli.

Menntavísindasvið Háskóla Íslands.

Sótt af http://netla.hi.is/serrit/2018/framhaldskolinn_brennidepli/08.pdf

DOI: https://doi.org/10.24270/serritnetla.2019.8 